\title{
HUBUNGAN KEADAAN EKONOMI ORANGTUA DENGAN PRESTASI BELAJAR SISWA KELAS VIII DI MTs N 2 PADANGSIDIMPUAN
}

\author{
Lili Nur Indah Sari \\ Institut Agama Islam Negeri Padangsidimpuan \\ E-mail: lilidly89@gmail.com
}

\begin{abstract}
Abstrak
Penelitian ini adalah penelitian kuantitatif. Populasi dalam penelitian ini 64 kelas yang terdiri dari 129 siswa dengan jumlah sampel 32 orang yang diambil $25 \%$ dari jumlah populasi. Instrumen yang digunakan adalah angket dengan Tes. Angket bertujuan untuk memperoleh gambaran ekonomi orangtua siswa dan prestasi belajar siswa. Sebelum instrumen digunakan terlebih dahulu tes diuji cobakan untuk melihat tingkat validitas dan reabilitas intrumen. Analisis data yang digunakan adalah korelasi product moment, koefisien determinasi, uji signifikan dan uji tingkat pencapaian. Setelah dilakukan perhitungan terhadap data untuk melihat hubungan variabel X dengan variabel $Y$ diperoleh $r$ hitung sebesar 0,097, sehingga diperoleh ada hubungan keadaan ekonomi orangtua dengan prestasi belajar siswa kelas VIII MTsN 2 Padangsidimpuan, tetapi dengan tingkat hubungan sangat rendah sebesar $0,9 \%$. Hal ini terbukti dari koefisien korelasi yang diperoleh sebesar $r_{x y}=0,097$ sedangkan $r_{\text {tabel }}=0,029$ pada taraf signifikan 5\% Pada keadaan ekonomi orangtua tergolong baik yakni dengan persentase $61 \%$ yang berada pada interval $57 \%$ - $61 \%$. Prestasi belajar tergolong sangat baik dengan nilai rata rata 84,5 yang berada pada interval 85-87. Dengan demikian diperoleh $t_{\text {hitung }}<t_{\text {tabel, }}$ yaitu $0,097<1,697$, dapat disimpulkan ada hubungan antara variabel $\mathrm{X}$ dengan variabel $\mathrm{Y}$ tetapi dengan tingkat hubungan yang sangat rendah. Dengan demikian hipotesis dalam penelitian ini ditolak, yaitu tidak ada hubungan yang signifikan antara keadaan ekonomi orangtua dengan prestasi belajar siswa kelas VIII DI MTs N 2 Padangsidimpuan
\end{abstract}

Kata kunci : Keadaan Ekonomi dan Prestasi Belajar

\begin{abstract}
This research is quantitative research. The population in this study was 6 classes consisting of 129 students with a sample of 32 people taken $25 \%$ of the total population. The instrument used was a questionnaire with tests. Questionnaire aims to obtain a picture of the economic parents of students and student achievement. Before the instrument is used first, the test is tested to see the level of instrument validity and reliability. Analysis of the data used is the product moment correlation, the coefficient of determination, test significant and test the level of achievement. After calculating the data to see the relationship between variable $X$ and $Y$, the $r$ count was 0.097 , so that there was a relationship between the economic
\end{abstract}


situation of the parents and the learning achievement of the eighth grade students of MTsN 2 Padangsidimpuan, but with a very low relationship level of $0.9 \%$. This is evident from the correlation coefficient obtained by rxy $=0.097$ while rtable $=0.029$ at a significant level of $5 \%$. In economic conditions, parents are classified as good with a percentage of $61 \%$ at intervals of $57 \%-61 \%$. Learning achievement is classified as very good with an average value of 84.5 in the $85-87$ interval. Thus obtained tcount $<$ ttable, that is $0.097<1.697$, it can be concluded that there is a relationship between variable $\mathrm{X}$ with variable $\mathrm{Y}$ but with a very low level of relationship. Thus the hypothesis in this study was rejected, namely there was no significant relationship between the economic situation of parents with the learning achievement of students of class VIII IN MTs N 2 Padangsidimpuan

Keywords: State of the Economy and Learning Achievement

\section{PENDAHULUAN}

Pendidikan yaitu menyangkut kegiatan belajar mengajar yang dilakukan secara sengaja atau tidak sengaja, pendidikan adalah suatu pembekalan atau persiapan yang tidak ada pada masa anak-anak, yang akan tetapi membutuhkannya pada waktu dewasa. Kebodohan sampai ketertinggalan oleh karena itu manusia sebagai pusat pendidikan maka manusia harus menjadikan pendidikan sebagai alat pembebasan untuk mengantarkan manusia menjadi makhluk yang bermartabat. ${ }^{25}$ Pendidikan sering diartikan sebagai usaha manusia untuk menumbuhkan dan mengembangkan potensi-potensi pembawaan baik jasmani maupun rohani sesuai dengan nilainilai yang ada di dalam masyarakat dan kebudayaan. Dalam perkembangannya,istilah pendidikan atau paedagogie berarti bimbingan atau pertolongan yang diberikan sengaja oleh orang dewasa agar menjadi dewasa.

Pada prinsipnya, pengungkapan hasil belajar ideal meliputi segenap ranah psikologis yang berubah sebagai akibat pengalaman dan proses belajar siswa. Namun demikian, pengungkapan perubahan tingkah laku seluruh ranah itu, khususnya ranah rasa murid, sangat sulit. Prestasi adalah hasil kerja nyata dengan standar baik kualitas maupun kuantitas yang di hasilkan setiap siswa nya. Dengan adanya prestasi yang tinggi sangat dibutuhkan untuk dapat bekerja sama antar siswa serta dapat mencapi tujuan sekolah. Tetapi sebaliknya dengan adanya siswa yang memiliki prestasi rendah akan sukar untuk mencapai hasil kerja yang baik, serta

\footnotetext{
${ }^{25}$ Firdaus, Pendidikan Berbasis Realitas Sosial (Jogjakarta: Logung Pustaka, 1991), hlm. 1
} 
siswa itu akan segera menyerah daripada beerusaha untuk mengatasi kesukaran tersebut. Hal ini akan berlainan apabila siswa mempunyai prestasi yang tinggi, sebab dengan prestasi yang tinggi para siswa akan berusaha untuk mengatasi kesukaran dalam menjalankan tugas danpekerjaan yang diberikan guru. Kunci pokok untuk memperoleh ukuran data hasil belajar siswa sebagaimana yang terurai diatas adalah mengetahui garis-garis indikato (petunjuk adanya prestasi tertentu) dikaitkan dengan jenis prestasi yang hendak diungkapkan atau diukur. ${ }^{26}$

Kesadaran akan tanggung jawab mendidik dan membina anak secara terus menerus perlu dikembangkan kepada setiap orangtua, mereka juga perlu dibekali teori-teori pendidikan modren sesuai dengan perkembangan zaman. Dengan demikian tingkat dan kualitas materi pendidikan yang diberikan dapat digunakan anak untuk menghadapi lingkungan yang selalu berubah. Bila hal ini dapat dilakukan setiap orangtua, maka generasi mendatang akan mempunyai kekuatan mental akan menghadapi perubahan dalam masyarakat.

keadaan ekonomi adalah total jumlah pendapatan dari semua anggota keluarga. Pendapatan keluarga yang rendah secara tidak langsung berakibat pada rendahnya kemampuan keluarga untuk memenuhi kebutuhan sehari-hari. Rendahnya pendapatan keluarga akan sangat berdampaknya rendahnya daya beli keluarga. Suatu perekonomian dikatakan mengalami pertumbuhan atau berkembang apabila tingkat kegiatan ekonominya lebih tinggi daripada apa yang dicapai pada masa sebelumnya.

Krisis ekonomi mengakibatkan semakin banyaknya penderitaan dan kesengsaraan rakyat, hal tersebut terbukti dengan semakin bertambahnya tingkat kemiskinan,pengangguran,hak dan perlindungan tenaga kerja tidak terjamin,kriminalitas, anak-anak jalanan serta semakin banyaknya anak-anak yang putus sekolah karena terbentur ekonomi. ${ }^{27}$ Sebagai contoh, anak dapat belajar apabila terdapat fasilitas-fasilatas atau sarana penunjang belajar,orangtua status sosial ekonomi rendah belum tentu berpendidikan tinggi.Dalam kondisi tersebut,kesempatan untuk meningkatkan prestasi belajar lebih besar di dapatkan individu yang memiliki orang tua dengan status sosial ekonomi tinggi. Apabila kebutuhan tersebut tidak dapat terpenuhi akan menghambat belajar anak, dan mengalami tekanan - tekanan fundamental seperti dalam memperoleh nafkah

\footnotetext{
${ }^{26}$ Mubbin Syah, Psikologi Belajar ( Jakarta:PT Grafindo, 2004), hlm,. 213-214.

${ }^{27}$ W.A. Garungan, Psikologi Sosial (Bandung: Eresco, 1998), hlm. 181-182.
} 
sehari-hari yang kurang dapat mencurahkan perhatian yang lebih mendalam terhadap pendidikan anak.

Keadaan ekonomi orangtua siswa turut mendukung siswa dalam pengadaan sarana \& prasana belajar, yang akan memudahkan \& membantu pihak sekolah untuk meningkatkan proses belajar mengjar membutuhkan biaya yang tidak sedikit. Pada kenyataannya orangtua banyak yang kurang memperhatikan masalah-masalah anak nya. Misalnya dalam masalah pendidikan, anak mempunyai potensi akademik baik, tetapi orangtua tidak menyediakan alat-alat yang dapat menyalurkan potensinya, dikarenakan keadaan ekonomi orangtua sangat rendah sehingga tidak bisa mengembangkan keahlian yang di miliki. Karena kebutuhan pendidikan tidak tersedia pada anak, maka prestasi belajarnya di sekolah rendah. Dan tidak semua siswa yang memiliki prestasi yang baik dari keadaan ekonomi yang tinggi dan sebaliknya tidak semua siswa yang dari keadaan ekonomi yang rendah memiliki prestasi yang buruk.

permasalahan yang terjadi pada siswa MTsN 2 Padangsidimpuan pada kenyataannya bahwa peserta didik memiliki prestasi yang berbeda - beda ,teramat penting latar belakang ekonomi yang terkadang amat mencolok antara satu peserta didik dengan peserta didik yang lain.

\section{KAJIAN TEORI}

\section{Ekonomi Orangtua}

\section{a. Pengertian Ekonomi}

Ekonomi menurut Kamus Umum Bahasa Indonesia, yaitu pengetahuan mengenai asasasas penghasilan (produksi), pembagian (distribusi) dan pemakaian barang-barang serta kekayaan (seperti halnya keuangan, perindustrian, perdagangan barang-barang serta kekayaan) di lingkungan tempat dia tinggal. Hal demikian merupakan tuntutan dasar untuk memenuhi segala kebutuhan. ${ }^{28}$ Dan defenisi yang paling populer tentang ekonomi adalah segalah aktivitas yang berkaitan dengan produksi dan distribusi diantara orang-orang. ${ }^{29}$ Islam memberikan petunjuk atas semua aktifitas manusia, termasuk ekonomi. Oleh karenanya, tujuan ekonomi islam tidak lepas dari tujuan diturunkannya syariat Islam, yaitu, untuk

\footnotetext{
${ }^{28}$ Depertemen Pendidikan Dan Kebudayaan, Kamus Besar Bahasa Indonesia (Jakarta: Balai Pustaka,1982), hlm. 220 .

${ }^{29}$ Amiur Nuruddin \& Agustianto, Dasar-dasar Ekonomi Islam (Bandung: Citapustaka Media, 2006), hlm. 43.
} 
mencapai falah (kesejahteraan/keselamatan) baik dunia maupun akhirat. ${ }^{30}$ Islam menyerukan pemeluk-pemeluknya untuk menikmati anugrah Allah Swt. Islam menyamakan usaha untuk menJelaslah bahwa pencapaian tingkat pertumbuhan ekonomi yang tinggi harus menjadi salah satu tujuan-tujuan ekonomis masyarakat, karena hal itu merupakan manifestasi dari usaha yang terus menerus, untuk memanfaatkan sumber-sumber daya yang di sediakan oleh Allah untuk kepentingan dan peningkatan taraf hidup manusia, dan demikian menunjang usaha untuk mencapai tujuan diciptakannya manusia. Demikian juga islam melarang pemeluknya untuk mengemis dan menyuruh mereka untuk berusaha sendiri untuk mencari nafkah.

Jelas lah bahwa pencapaian tingkat pertumbuhan ekonomi yang tinggi harus jadi salah satu tujuan-tujuan ekonomis masyarakat, karena hal itu merupakan hasil menifestasi dari usaha terus menerus, untuk memanfaatkan sumber-sumber daya yang disediakan oleh Allah untuk kepentingan dan peningkatan taraf hidup manusia, dan demikian menunjang usaha untuk mencapai tujuan diciptakannya manusia. Demikian juga Islam melarang pemeluknya untuk mengemis dan menyuruh mereka untuk berusaha sendiri untuk mencari nafkah berupa pekerjaan. Penghasilan merupakan suatu hasil kerja yang berupa pendapatan yang di terima oleh orangtua yang nantinaya digunakan untuk memenuhi kebutuhan sehari - hari.

\section{b. Tingkatan Ekonomi Orangtua}

Tingkatan ekonomi orangtua dapat dibagi 3, yaitu;

a) Ekonomi mampu/kaya

Ekonomi mampu/kaya ini mempunyai pendapatan tinggi, sehingga mereka dapat hidup layak. Contoh: pekerjaan yang tergolong dalam ekonomi mampu/kaya adalah pejabat pemerintah setempat, pegawai swasta, insinyur, dan kelompok profesional lainnya.

b) Ekonomi menengah

Lapisan masyarakat tergolong lapisan lapisan ekonomi menengah ini mempunyai pendapatan yang dikatakan cukup untuk memenuhi kebutuhan hidupnya. Contoh: pekerjaan yang tergolong ekonomi menengah adalah pedagang dan pegawai negeri.

c) Ekonomi miskin

\footnotetext{
${ }^{30}$ Nurul Huda Dkk, Keuangan Publik Islam Pendekatan Teoritis dan Sejarah (Jakarta:Kencana Prenada Media Group, 2012), hlm. 1.
} 
Lapisan masyarakat yang tergolong lapisan ekonomi miskin ini memiliki pendapatan yang minnim. Contohnya: pekerjaan yang tergolong ekonomi miskin ini adalah buruh petani, uruh bangunan, buruh pabrik, dan buruh yang sejenis tidak tetap. ${ }^{31}$

Keadaan ekonomi yang memadai dapat diukur dengan tingkat pendapatan orangtua, jumlah keluarga, dan besarnya beban tanggung jawab biaya yang dikeluarkan untuk masa waktu tertentu.

\section{Prestasi Belajar}

\section{a. Pengertian Prestasi}

Pada umumnya orang berpendapat bahwa intelegensi merupakan bekal potensial yang akan memudahkan dalam belajar dan pada gilirannya akan menghasilkan performansi yang optimal. Sehingga sangatlah wajar apabila mereka yang memiliki intelegensi tinggi diharapkan akan dapat di peroleh prestasi belajar yang tinggi pulak.

Salah satu defenisi intelegensi memang menyebutkan bahwa intelegensi antara lain, merupakan ablity to learn (kemampuan untuk belajar). Begitu juga kemudahan dalam belajar disebabkan oleh tingkat intelengensi yang tinggi terbentuk oleh ikatan - ikatan syaraf (neural bands) antara stimulus dan respon yang mendapat penguatan. ${ }^{32}$ Pengertian prestasi yang paling sederhana adalah yang terdapat dalam Kamus Besar Indonesia Populer, yaitu hasil yang telah di capai, ${ }^{33}$ ada juga yang mengartikan dengan hasil yang telah dicapai, dilakukan, dikerjakan. ${ }^{34}$ Perstasi merupakan hasil penilaian pendidikan atas pekembangan dan kemajuan siswa dalam belajar. Prestasi menunjukan hasil dari pelaksanaan kegiatan yang diikuti siswa disekolah, kegiatan belajar yang diikuti siswa dapat diukur melalui penguasaan materi yang diajarkan guru serta nilai-nilai yang terkandung dalam kurikulum. Bagaimanapun sebuah prestasi tidak akan pernah di hasilkan oleh seseorang bila tidak melakukan kegiatan. Dalam kenyatan nya untuk mendapatkan prestasi seseorang harus melalui berbagai tantangan dan rintangan yang harus dihadapi.

Dari beberapa pengertian prestasi yang dikemukakan oleh para ahli diatas telihat jelas perbedaan pada kata-kata tertentu sebagai penekanan, namun pada intinya sama yaitu hasil yang dapat diukur dari suatu kegiatan yang telah dikerjakanatau diciptakan yang diperoleh dengan keuletan kerja baik secara individu maupun kelompok dalam kegiatan tertentu.

\footnotetext{
${ }^{31}$ Abdul Basith, Ekonomi Kemasyarakatan Visi dan Perbedaan Sektor Ekonomi Rendah (Malang:UINMALIKI PRESS, 2011), H1m., 3.

${ }^{32}$ Syaifuddin Azwar, Psikologi Intelegensi (Yogyakarta Pustaka Pelajar, 2002), hlm. 163.

${ }^{33}$ Hanapi Ridwan dan Lia Mariati, Kamus Besar Indonesia Populer (Surabaya: Tiga Dua,1992), hlm. 251.

${ }^{34}$ Muhammad Ali, Kamus Lengkap Bahasa Indonesia Moderen ( Jakarta: Pustaka Insani), hlm. 323.
} 


\section{b. Tipe-Tipe Prestasi Belajar}

Pencapaian prestasi belajar atau hasil belajar siswa, merujuk kepada aspek-aspek kognitif, afektif dan psikomotor. Oleh karena itu ketiga aspek diatas juga harus menjadi indikator prestasi belajar. Artinya, prestasi belajar harus mencapai aspekaspek kognitif, afektif dan psikomotor. Menurut Nana Sudjana yang dikutip oleh Tohirin, ketiga aspek di atas tidak berdiri sendiri, tetapi merupakan suatu kesatuan yang tidak terpisahkan, bahkan membentuk hubungan hierarki. Di bawah ini akan dijelaskan beberapa jenis dari tipe prestasi belajar, baik prestasi belajar bidang kognitif, bidang psikomotorik maupun bidang afektif dijelaskan sebagai berikut:

a. Tipe Prestasi Belajar Bidang Kognitif

Menurut Nana Sudjana sebagaimana dikutip oleh Tohirin dijelaskan beberapa tipe-tipe prestasi belajar bidang kognitif sebagai berikut:

1) Tipe presstasi belajar pengetahuan hapalan (knowledge)

2) Tipe prestasi belajar pemahaman (congprehention)

3) Tipe prestasi belajar penerapan (aplikasi)

4) Tipe prestasi belajar analisis

5) Tipe prestasi belajar sintesis

6) Tipe prestasi belajar evaluasi. ${ }^{35}$

b. Tipe Prestasi Belajar Bidang Afektif

Bidang afektif berkenaan dengan sikap dan nilai. Sikap seseorang bisa diramalkan perubahan-perubahannya, apabila seseorang telah menguasai bidang kognitif tingkat tinggi. Ada kecenderungan bahwa prestasi belajar bidang afektif kurang mendapat perhatian dari guru. Para guru cenderung lebih memperhatikan atau menekankan pada bidang kognitifnya semata. Tipe prestasi belajar, afektif pada tampak siswa dalam berbagai tingkah laku, seperti atensi atau perhatian terhadap pelajaran, disiplin, motivasi belajar, menghargai guru dan teman, kebiasaan belajar dan lain-lain. Meskipun bahan pelajaran berisikan bidang kognitif, tetapi bidang afektif harus menjadi bagian integral dari bahan tersebut, dan harus tampak dalam proses belajar dan prestasi belajar yang dicapai. hlm. 151 .

${ }^{35}$ Tohirin, Psikologi Pembelajaran Pendidikan Agama Islam (Jakarta:PT.Raja Grafindo Persada, 2008), 
Sebagaimana dijelaskan oleh Tohirin bahwa tingkatan bidang afektif sebagai tujuan dan tipe prestasi belajar mencakup:

1. Receiving atau attending, yakni, kepekaan dalam menerima rangsangan (stimulus) dari luar yang datang pada siswa, baik dalam bentuk masalah situasi maupun gejala.

2. Responding atau jawaban, yakni reaksi yang diberikan seseorang terhadap stimulus yang datang dari luar.

3. Valuing (penilaian), yakni berkenaan dengan penilaian dan kepercayaan terhadap gejala atau stimulus.

4. Organisasi yakni pengembagan nilai kedalam suatu sistem organisasi termasuk menentukan hubungan suatu nilai dengan nilai lain dan kemantapan, prioritas nilai yang telah dimilikinya.

5. Karakteristik dan internalisasi nilai, yakni keterpaduan dari semua sistem nilai yang telah dimiliki oleh seseorang, yang mempengaruhi pada kepribadian dan prilakunya. $^{36}$

c. Tipe Prestasi Belajar Bidang Psikomotor

Tipe prestasi belajar bidang psikomotor tampak dalam keterampilan (skill), dan kemampuan bertindak seseorang. Adapun tingkatan keterampilan itu meliputi:

1. Gerakan refleks (keterampilan pada gerakan yang sering tidak disadari karena sudah merupakan kebiasaan)

2. Keterampilan pada gerakan-gerakan dasar.

3. Kemampuan perspektual termasuk didalamnya membedakan visual, membedakan auditif motorik dan lain-lain.

4. Kemampuan dibidang fisik seperti kekuatan, keharmonisan dan ketepatan.

5. Gerakan-gerakan yang berkaitan dengan skill, mulai dari keterampilan sederhana sampai pada keterampilan yang kompleks

6. Kemampuan yang berkenaan dengan non decursive komunikasi seperti gerakan ekspresif dan interpreatif. ${ }^{37}$

Tipe-tipe prestasi belajar seperti dikemukakan diatas tidak berdiri sendiri, tetapi slalu berhubungan satu sam lain. Seseorang (siswa) yang berubah tingkat

\footnotetext{
${ }^{36} \mathrm{Ibid}$.

${ }^{37} \mathrm{Ibid}$.
} 
kognisinya sebelumnya dalam kadar tertentu dalam berubah pula sikap dan prilakunya. Carl Rogers seperti yng dikutip oleh Tohirin dalam buku karangan sudjana, menyatakan bahwa "seseorang yang telah menguasai tingkat kognitif maka prilaku orang tersebut sudah bisa diramalkan".

Dari penjelasan diatas dapat dilihat bahwa tipe prestasi belajar yang harus dicapai dalam pendidikan tidak hanya pada bidang kognitif dan afektif akan tetapi psikomotoriknya juga, agar ilmu-ilmu yang siswa dapatkan dalam pembelajaran dapat diaplikasikan dalam kehidupan sehari-hari.

\section{d. Faktor Ekonomi Yang Dapat Memepengaruhi Prestasi Belajar}

Pengaruh keadaan ekonomi keluarga erat hubungannya dengan hasil belajar anak. Kebutuhan-kebutuhan anak harus terpenuhi adalah : makanan, pakaian, kesehatan dan fasilitas belajar seperti ruang belajar, kursi, meja, penerangan, bukubuku. Fasilitas belajar ini haya dapat hanya dapat terpenuhi jika orangtuanya mempunyai cukup uang. Jika anak hidup dalma keluarga yang miskin, kebutuhan anak kurang terpenuhi akibat kesehatan anak kurang sehingga belajar anak pun terganggu. Akibat yang lain adalah anak selalu dirundung kesedihan sehingga anak merasa minder dengan teman lain, ini pasti mengganggu prestasi belajar anak. ${ }^{38}$

Pemenuhan kebutuhan siswa di samping bertujuan untuk memberikan materi kegiatan secepat mungkin, juga materi pelajaran yang sudah diselesaikan dengan kebutuhan biasanya menjadi lebih menarik. Dengan demikian maka akan lebih membantu pelaksaan proses belajar mengajar. Adapun yang menjadi kebutuhan jasmaniadalh seperti makan, minum, tidur, pakaian dan lain-lain. ${ }^{39}$

\section{METODE PENELITIAN}

Metode yang digunakan dalam penelitian ini adalah metode kuantitatif, Jenis penelitian ini adalah penelitian korelasi (correlation research). Jenis penelitian korelasi bermaksud mendeteksi seberapa jauh variasi pada suatu faktor yang berhubungan dengan variasi atau lebih faktor lain berdasarkan koefisien korelasinya. ${ }^{40}$

Hipotesis statistik

\footnotetext{
${ }^{38}$ Slameto, Belajar dan Faktor yang Mempengaruhinya (Jakarta: Rineka Cipta 1991), hlm. 54-60

${ }^{39}$ Sardiman, AM, Interaksi dan Motivasi BelajarMengajar (Jakarta : Raya Gravindo Persada 2002), hlm.

${ }^{40}$ Usman Husaini Dkk, Metodologi Penelitian Sosial (Jakarta : PT Bumi Aksara,2011), hlm. 5.
} 
Ha : tidak terdapat hubungan antara ekonomi keluarga dengan prestasi belajar siswa

$\mathrm{H}_{0} \quad$ : terdapat hubungan antara ekonomi keluarga dengan prestasi belajar siswa

\section{HASIL PENELITIAN}

1. Data Tentang Ekonomi Orangtua

Berdasarkan dari hasil perhitungan jawaban responden terhadap pertanyaanpertanyaan yang tertera dalam angket mengenai ekonomi orangtua siswa kelas VIII VIII DI MTs N 2 PADANGSIDIMPUANdengan menggunakan perhitungan statistik, maka diperoleh skor-skor variabel ekonomi orangtua. Gambaran keadaan ekonomi orangtua berdasarkan skor angket yang diperoleh dapat dilihat pada gambaran data seperti tabel dibawahini:

Tabel 1

Ukuran Penyebaran Dan Pemusatan Data

\begin{tabular}{|c|l|c|}
\hline No. & \multicolumn{1}{|c|}{ Statistik } & X \\
\hline 1 & Skor tertinggi & 79 \\
\hline 2 & Skor terendah & 52 \\
\hline 3 & Range & 27 \\
\hline 4 & Jumlah interval & 6 \\
\hline 5 & Interval kelas & 5 \\
\hline 6 & Mean & 61,15 \\
\hline 7 & Median & 67,9 \\
\hline 8 & Modus & 65 \\
\hline 9 & Standar Deviasi & 6,842 \\
\hline
\end{tabular}

Tabel 2

Gambaran Ekonomi Orangtua Siswa Kelas VIII MTs N 2 PADANGSIDIMPUAN

\begin{tabular}{|c|c|c|}
\hline Interval Nilai & $\begin{array}{c}\text { Frekuensi } \\
\text { Absolute }\end{array}$ & $\begin{array}{c}\text { Frekuensi Relatif } \\
(\mathbf{\%})\end{array}$ \\
\hline $52-56$ & 8 & 25 \\
\hline $57-61$ & 10 & 31,25 \\
\hline $62-66$ & 7 & 21,87 \\
\hline $67-71$ & 4 & 12,5 \\
\hline $72-76$ & 2 & 6,25 \\
\hline $77-81$ & 1 & 3.12 \\
\hline Jumlah & 32 & 100 \\
\hline
\end{tabular}


Dari tabel diatas diketahui bahwa penyebaran skor menunjukan bahwa responden yang berada pada interval kelas 52-56 sebanyak 8 orang (25\%), interval kelas 57-61s ebanyak 10 orang (31,25\%), interval kelas 62-66 sebanyak 7 orang (21,87\%), interval 67-71 sebanyak 4 orang (12,5\%), interval kelas 72-76sebanyak 2 orang $(6,25 \%)$, dan interval 77-81 sebanyak 1 orang(3.12\%).

Selanjutnya untuk mengetahui tingkat pencapaian variabel ekonomi orangtua siswa MTs N 2 Padangsidimpuan sebagai berikut:

Tabel 3

Distribusi tingkat pencapaian ekonomi orangtua siswa

\begin{tabular}{|c|c|c|}
\hline No. & Skor & Interpretasi Penilaian ekonomi orangtua \\
\hline 1 & $0 \%-20 \%$ & Sangat tidak baik \\
\hline 2 & $21 \%-40 \%$ & Tidak baik \\
\hline 3 & $41 \%-60 \%$ & Kurang baik \\
\hline 4 & $61 \%-80 \%$ & Baik \\
\hline 5 & $81 \%-100 \%$ & Sangat baik \\
\hline
\end{tabular}

Dari perhitungan di atas tingkat pencapaian ekonomi orangtua siswa MTsN 2 Padangsidimpuan termasuk dalam kategori kurang baik. Hal ini dapat dilihat dari hasil analisis perhitungan yang menunjukan nilai $56 \%$ berada diantara interval 61\% - 80\% (berdasarkan tabel distribusi tingkat pencapaian pada metedologi penelitian).

2. Prestasi belajar siswa

Tabel 4

Gambaran Prestasi Belajar Siswa MTsN 2 Padangsidimpuan

\begin{tabular}{|c|c|c|c|}
\hline No. & Interval & F & Persentase (\%) \\
\hline 1 & $76-78$ & 5 & 15,625 \\
\hline 2 & $79-81$ & 2 & 6,25 \\
\hline 3 & $82-84$ & 4 & 12,5 \\
\hline 4 & $85-87$ & 15 & 46,875 \\
\hline 5 & $88-90$ & 6 & 18,75 \\
\hline \multicolumn{2}{|l}{ Jumlah } & 32 & 100 \\
\hline
\end{tabular}

Sesuai dengan perhitugan bahwa rata - rata nilai diperoleh siwa adalah 84,5 . Hasil ini jika dilihat dari kriteria penilaian maka tergolong pada kategori sangat baik, artinya prestasi belajar siswa yang di peroleh siswa MTsN 2 Padangsidimpuan kebanyakan memperoleh sangat baik walaupun dalam keadaan ekonomi orangtua yang cukup. 
3. Hubungan Keadaan Ekonomi Orangtua dengan Prestasi Belajar Siswa

Untuk melihat hubungan keadaan ekonomi siswa dengan prestasi belajar siswa dengan menggunakan uji korelasi. Diperoleh hasilnya sebagai berikut:

\begin{tabular}{|ll|r|r|}
\hline \multicolumn{1}{|c|}{ Correlations } \\
& & $\begin{array}{c}\text { Ekonomi } \\
\text { Orangtua }\end{array}$ & Prestasi Belajar \\
\hline Ekonomi Orangtua & Pearson Correlation & 1 & .097 \\
& Sig. (2-tailed) & & .597 \\
& $\mathrm{~N}$ & 32 & 32 \\
\hline Prestasi Belajar & Pearson Correlation & .097 & 1 \\
& Sig. (2-tailed) & .597 & 32 \\
& $\mathrm{~N}$ & 32 & \\
\hline
\end{tabular}

Dengan nilai yang diperoleh dapat menggambarkan sejauhmana keeratan hubungan anatara variabel ekonomi keluarga dengan variabel prestasi belajar dengan nilai $r$ thitung 0,097. Diketahui $r$ tabel sebesar 0,0291, nilai $r$ hitung 0,097 >0,0291 . sehingga dapat dinyatakan bahwa hipotesis $\left(\mathrm{H}_{0}\right)$ diterima. Dari hasil perhitungan data tersebut dapat disimpulkan terdapat hubungan antara ekonomi keluarga dengan prestasi belajar siswa di MTsN 2 Padangsidimpuan.

Berdasarkan hasil uji analisis statistik nonparametrik dengan uji korelasi Spearman Rank Order Correlation diperoleh koefisien korelasi kedua variabel sebesar 0,097 ini artinya hubungan diantara kedua variabel yaitu ekonomi orangtua dengan prestasi belajar siswa di MTsN 2 Padangsidimpuan. Hasil korelasi ini menjelaskan bahwa semakin tinggi ekonomi orangtua semakin tinggi prestasi belajar siswa, begitupun sebaliknya, semakin rendah ekonomi orangtua akan diikuti dengan rendahnya prestasi belajar. Siswa yang memiliki ekonomi orangtua yang tinggi maka yakin dapat mengandalkan kemampuannya melalui prestasi belajar yang tinggi. Siswa yang memiliki ekonomi orangtua yang tinggi dapat menampilkan prestasi belajar yang tinggi walaupun memiliki teman sebaya yang memiliki kecerdasan yang sama. Siswa dengan ekonomi 
orangtua yang tinggi tidak akan merasa minder dengan teman sebaya yang berada di kelas dikarenakan mereka juga mendapatkan prestasi belajar yang tinggi walaupun memiliki kecerdasan yang sama. Siswa dengan ekonomi orangtua yang tinggi mempunyai keyakinan dapat mengembangkan kemampuannya, mereka akan dapat menyelesaikan tugas-tugas yang sulit. Keyakinan menyelesaikan tugastugas yang sulit akan dapat meningkatkan prestasi belajarnya. Siswa tersebut mempunyai keyakinan dapat mengembangkan kemampuan dan menentukan hasil prestasi belajarnya. Selain itu di dalam diri siswa terdapat adanya keyakinan dalam menentukan seberapa tinggi usaha siswa dalam aktifitas mencapai prestasi belajar. Keyakinan dengan ketahanan usaha dalam menghadapi taraf kesulitan tugas yang berada pada situasi yang tidak mendukung dapat meyakinkan siswa dapat mengatasi hal-hal tersebut. Ekonomi orangtua mempengaruhi tingkat prestasi belajar ketika sedang melaksanakan tugas dan mempengaruhi tingkat pencapaian prestasi individu.

\section{KESIMPULAN}

Dari hasil penelitian, dapat ditarik sebagai kesimpulan sebagaai berikut :

1. Ekonomi orangtua siswa kelas VIII di MTs N 2 Padangsidimpuan tergolong baik $(61 \%)$ berdasarkan interprestasi skor.

2. Prestasi belajar siswa yang diambil dari nilai raport siswa dengan nilai rata rata 84,5 tergolong baik sekali.

3. Berdasarkan hasil perhitungan yang diperoleh nilai korelasi product moment (rxy) antara dua variabel ekonomi orangtua dan prestasi belajar siswa sebesar 0,097 mempunyai hubungan yang lemah. Selanjutnya tingkat signifikansi korelasi tersebut di lakukan dengan melihat $\mathrm{r}$ tabel $\left(\mathrm{r}_{\mathrm{t}}\right)$ pada taraf signifikansi $5 \%(0,05)$ adalah 0.361 dan $\mathrm{t}_{\text {hitung }}<\mathrm{t}_{\text {tabel }}$ yaitu0,534 $<1.697$. hipotetis dalam penelitian di tolak yaitu $\mathrm{t}_{\text {hitung }}<\mathrm{t}_{\text {tabel }}$ maka Ho ditolak artinya tidak signifikan antara keadaan ekonomi orangtua dengan prestasi belajar siswa kelas VIII MTsN 2 Padangsidimpuan, yaitu hubungannya lemah atau tidak signifikan antara keadaan ekonomi orangtua dengan prestasi belajar siswa kelas VIII MTsN 2 Padangsidimpuan. 


\section{DAFTAR PUSTAKA}

Abdul Basith, Ekonomi Kemasyarakatan Visi dan Perbedaan Sektor Ekonomi Rendah, Malang:UIN MALIKI PRESS, 2011.

Amiur Nuruddin, Dasar-dasar Ekonomi Islam, Bandung: Citapustaka Media, 2006.

Depertemen Pendidikan Dan Kebudayaan, Kamus Besar Bahasa Indonesia, Jakarta: Balai Pustaka, 1982.

Firdaus, Pendidikan Berbasis Realitas Sosial, Jogjakarta: Logung Pustaka, 1991.

Hanapi Ridwan dan Lia Mariati, Kamus Besar Indonesia Populer, Surabaya: Tiga Dua, 1992.

Mubin Syah, Psikologi Belajar, Jakarta: PT Grafindo, 2004.

Muhammad Ali, Kamus Lengkap Bahasa Indonesia Moderen, Jakarta: Pustaka Insani.

Nurul Huda dkk, Keuangan Publik Islam Pendekatan Teoritis dan Sejarah, Jakarta: Kencana Prenada Media Group, 2010.

Sardiman, AM, Interaksi dan Motivasi BelajarMengajar Jakarta : Raya Gravindo Persada 2002.

Slameto, Belajar dan Faktor yang Mempengaruhinya Jakarta: Rineka Cipta 1991.

Syaifuddin Azwar, Psikologi Intelegensi, Yogyakarta:Pustaka Belajar, 2002.

Tohirin, Psikologi Pembelajaran Pendidikan Agama Islam, Jakarta: PT. Raja Grafindo Persada, 2008.

Usman Husaini Dkk, Metodologi Penelitian Sosial, Jakarta : PT Bumi Aksara,2011.

W.A. Garungan, Psikologi Sosial, Bandung: Eresco, 1998. 